\title{
Menumbuhkan Kemampuan Berpikir Kreatif Peserta Didik SMP Melalui Perangkat Pembelajaran Berbasis Teori M-APOS
}

\author{
Ihksan Apria Suske, Yerizon, Armiati \\ Program Studi Magister Pendidikan Matematika, FMIPA Universitas Negeri Padang \\ ihksanapria@gmail.com \\ yerizon@fmipa.unp.ac.id
}

\begin{abstract}
The ability to think creatively is an ability that is expected to be mastered by students but is still low. Students lack the ability to solve a problem in a various ways.The purpose of this study is to produce a learning tool based on M-APOS theory to improve students' creative thinking abilities.The research method used in this research is research and development which consists of three stages, namely the initial investigation stage, the development stage and the assessment stage.In this section what is done is the preliminary research stage. The instruments used were interview and questionnaire guidelines.The results of the study are: 1) inadequate school facilities and infrastructure, 2) student learning outcomes are still low because students are accustomed to accept what is taught and do not repeat the lessons at home, 3) worksheets that are used by students is not attractive, 4) in the learning process students prefer group learning, 5) students want the questions contained in LKPD to be daily life problems, 6) the learning environment of students who are in the hills and close to the highway, 7) learning styles favored by students are in the form of solving problems in the form of images related to daily life problems, 8) the appearance of worksheets that are liked by students is LKPD which has pictures and attractive color.
\end{abstract}

Keywords : Teori M-APOS, kemampuan berpikir kreatif, worksheet

his is an open access article distributed under the Creative Commons 4.0 Attribution License, which permits unrestricted use, distribution, and reproduction in any medium, provided the original work is properly cited. 02018 by author and Universitas Negeri Padang.

\section{PENDAHULUAN}

Matematika merupakan suatu alat yang digunakan oleh manusia untuk berpikir. Matematika memiliki fungsi sebagai sarana untuk mengembangkan berbagai aspek kemam puan seperti kemampuan kreatif, pemecahan masalah, berpikir logis, rasional dan kritis. Pembelajaran matematika tidak hanya terfokus kepada hasil yang dicari tetapi lebih mene kankan kepada proses bagaimana menemukan hasil tersebut. Melalui pembelajaran matematika peserta didik bisa mengembangkan aktifitas kreatif yang melibatkan intuisi dan imajinasi yang dimilki oleh peserta didik (Rhamayanti dan Nurdalilah, 2018). Berpikir kreatif adalah suatu kebiasaan dari sebuah pemikiran yang sering dilatih dengan memperhatikan intuisi dan bagaimana peserta didik berimajinasi. melalui pemikiran yang kreatif itulah peserta didik bisa mengungkap suatu kemungkinan-kemungkinan yang baru, melihat dari sudut pandang yang berbeda dan bisa mengembangkan ide-ide yang dimiliki secara terbuka.

Peserta didik yang berpikir kreatif dapat melihat apa yang tidak bisa dilihat oleh peserta didik lainnya serta bisa menemukan suatu solusi yang berbeda dari apa yang telah diajarkan sebelumnya. Hasil studi Trends International Mathematics And Science Study (TIMSS) menunjukkan pada tahun 2011 menyatakan bahwa kemampuan kreatif yang dimiliki oleh peserta didik di Indonesia tergolong rendah, hanya $2 \%$ peserta didik di Indonesia yang bisa menyelesaiakan soal-soal kategori tingkat tinggi yang sangat membutuhkan kemampuan berpikir kreatif masing-masing peserta didik untuk menyelesaikannya. Hasil ini didukung oleh hasil penelitian terdahulu (Mandasari, 2018; Widiastuti dan Putri, 2018; Kadir, 2017; Retno Marsitin, 2017; Abdul fatah, 2016; Elly's, 2015; Elda Herlina. 2013). Hasil yang sama juga juga dapat dilihat dari hasil tes pada penelitian pendahuluan yang dilakukan kepada peserta didik kelas VII SMPN 2 Bukit Sundi Kabupaten Solok yang terdiri dari 2 soal berpikir kreatif. Hasil dari tes dapat dilihat pada Tabel 1.

Berdasarkan Tabel 1 terlihat bahwa peserta didik yang memperoleh skor maksimal masih sangat sedikit pada setiap indikator soal, ini menunjukan rendahnya kemampuan berpikir kreatif peserta didik. Rendahnya kemampuan berpikir kreatif peserta didik berimplikasi 
kepada prestasi yang ingin dicapai oleh peserta didik. Hasil ini terjadi karena peserta didik terbiasa menerima apa yang diajarkan oleh guru tanpa mengembangkan imajinasi, ide-ide serta gagasan untuk memecahkan suatu persoalan dalam sudut pandang yang berbeda. Akibatnya kemampuan berpikir kreatif siswa kurang berkembang dengan optimal.

Tabel 1. Hasil Tes Kemampuan Berpikir Kreatif Peserta Didik

\begin{tabular}{|l|c|c|c|c|c|}
\hline \multirow{2}{*}{ Indikator } & \multirow{2}{*}{$\begin{array}{c}\text { No. } \\
\text { Soal }\end{array}$} & \multicolumn{5}{|c|}{ Persentase Jawaban Tiap } \\
\cline { 3 - 6 } & & $\mathbf{0}$ & $\mathbf{1}$ & $\mathbf{2}$ & $\mathbf{3}$ \\
\hline kelancaran & 1 & 60 & 32 & 8 & - \\
\hline & 2 & 56 & 28 & 16 & - \\
\hline kelenturan & 1 & 52 & 36 & 16 & - \\
\hline & 2 & 64 & 28 & 8 & - \\
\hline keaslian & 1 & 48 & 32 & 12 & 8 \\
\hline & 2 & 60 & 24 & 12 & 4 \\
\hline keterincian & 1 & 32 & 32 & 36 & - \\
\hline & 2 & 28 & 40 & 32 & - \\
\hline
\end{tabular}

Peneliti mengamati selama proses yang dilakukan dalam penelitian pendahuluan peserta didik kurang aktif terlibat dalam proses pembelajaran. Akibatnya peserta didik hanya mencontoh apa yang diajarkan oleh guru sehingga dalam menyelesaikan soal yang diberikan peserta didik hanya mencotoh konsep dari apa yang telah diajarkan guru sebelumnya tanpa mengembangkan ide serta gagasan yang dimiliki peserta didik itu sendiri. Hal tersebut tersebut menyeb abkan peserta didik kurang memiliki kemampuan menyelesaikan masalah dengan alternatif lain. Berdasarkan pengamatan dan hasil wawancara yang dilakukan dapat disimpulkan bahwa peserta didik sangat kesulitan menyelesaikan soal yang menuntut peserta didik untuk berpikir kreatif.

Pada saat peserta didik menyelesaikan soal-soal yang diberikan terlihat bahwa peserta didik sangat kesulitan untuk mengembangkan ide, menemukan solusi yang berbeda dan tidak bisa merinci jawaban dengan baik. LKPD yang digunakan sebagai sumber belajar belum memfasilitasi peserta didik dalam mengem bangkan kemampuan berpikir kreatif. Pada worksheet kurang terlihat langkah-langkah kegiatan apa yang harus dilakukan peserta didik untuk membangun pemahamannya. Pada umumnya worksheet memberikan materi secara umum, rumus, contoh soal dan latihan.
Berdasarkan hal tersebut maka LKPD yang digunakan selama ini perlu ditambahkan kegiatan yang dapat meningkatkan pemahaman dan kegiatan menemukan konsep pembelajaran agar peserta didik terbiasa menyelesaiakan permasalahan matematika dalam kehidupan sehari-hari (Khairani dkk, 2018).

Salah satu solusi untuk meningkatkan kemapuan berpikir kreatif peserta didik adalah mengembangkan suatu perangkat pembelajaran berbasis teori M-APOS. Teori M-APOS adalah modifikasi dari APOS (action, prosess, object dan schema). Langkah-langkah yang digunakan dalam teori M-APOS hampir sama dengan teori APOS hanya saja ada sedikit perbedaan pada fase aktivitas dimana pada teori APOS fase aktivitas dilaksanakan pada labor komputer sedangakan pada M-APOS fase aktivitas di labor komputer digantikan dengan memberikan LKPD kepada peserta didik(Nurlaelah, 2009; Yerizon, 2019).

APOS adalah sebuah teori pembelajaran yang dikhususkan dalam pembelajaran mate matika dalam bentuk kelompok belajar kecil dengan memperhatikan susunan mental dalam membangun suatu konsep pembelajaran (Arnawa, 2009). APOS merupakan sebuah pendekatan yang digunakan dalam sebuah pembelajaran khusunya matematika yang terintegrasi pada penggunaan komputer dan pembelajaran berkelompok dimana sangat memperhatikan kontruksi dari mental peserta didik dalam memahami konsep, ketrampilan sosial, komunikasi dan mencentuskan ide secara kreatif (Yerizon, 2019).

Teori APOS adalah sebuah teori pembelajaran yang memungkinkan peserta didik untuk membangun sebuah pengetahuan sendiri, mendorong pengetahuan, dan memyelesaikan masalah dengan cara terstruktur. Siswa mampu menganalisis banyak masalah yang muncul dalam memahami konsep dan mengembangkan pemahaman sebanyak mungkin melalui kontruksi mental yang dimulai melalui sebuah aksi yang dilakukan, diperkirakan menjadi sebuah proses dirangkum menjadi objek dan diuraikan menjadi sebuah skema (Dubinsky, 2010; Sri Wiji Lestari, 2014; Ahmad Murdikah, 2016; Voskoglou, 2013; Selvia Mandasari, 2018; Rohimah. 2017).

Teori M-APOS memiliki kelebihan dalam memahami suatu konsep belajar, membantu peserta didik untuk fokus pada pemecahan masalah karena dalam memecahkan suatu 
masalah pembelajaran akan melibatkan proses berpikir tingkat tinggi sehingga mampu meningkatkan kemampuan seperti berpikir kreatif peserta didik. Dalam suatu proses berpikir, suatu ide tidak dapat muncul secara tiba-tiba. Ide akan muncul setelah berbagai proses berpikir diolah sehingga akan melewati proses pengkontruksian mental peserta didik sebagai berikut: 1) Aksi, pada tahapan ini peserta didik akan diberikan ransangan terlebih dahulu, serta intruksi dalam melakukan suatu kegiatan yang sesuai dengan tahapan, 2) Proses, yaitu struktur mental yang melakukan kegiatan yang sama, namun seluruh kegiatan berdasarkan pemikiran peserta didik, 3) Objek, yaitu ketika proses transformasi sudah berada dalam pemikiran peserta didik, peserta didik sudah mampu menemukan konsep pembelajaran, dikarenakan peserta didik sudah bisa memahami bahwa proses transformasi sudah bisa dilakukan dalam satu kesatuan dan 4) skema, merupakan suatu kegiatan yang dirangkum dari aksi, proses dan objek dimana peserta didik sudah mampu untuk mengaitkan materi yang sudah dipelajari dan dipahami sebelumnya.

\section{METODE PENELITIAN}

Jenis penelitian yang dilakukan adalah Development Research. Penelitian ini merupakan suatu proses untuk mengembangkan suatu produk baru yang bertujuan untuk mengembangkan RPP dan LKPD berbasis teori M-APOS untuk meningkatkan kemampuan berpikir kreatif peserta didik kelas VII SMP. Perangkat yang akan dikembangkan adalah perangkat yang valid, praktis dan efektif. Penelitian mengadaptasi model pengembangan yang digunakan oleh Tjeerd Plomp yang terdiri dari tiga fase yaitu preliminary research phase, development or prototyping phase, dan assessment phase (Plomp dan Nieveen, 2013). Pada penelitian ini hanya dilaporkan pada preliminary research phase. Kegiatan yang dilakukan adalah analisis kebutuhan, analisis kurikulum, analisis karakteristik peserta didik, dan analisis konsep (Armiati et al, 2018).

\section{HASIL DAN PEMBAHASAN}

Pada preliminary research phase ini dilakukan untuk mengetahui permasalahan apa saja yang terdapat dalam proses belajar mengajar baik yang dirasakan oleh guru maupun peserta didik. Kemudian untuk mengetahui hal apa saja yang akan dibutuhkan untuk perangkat pembelajaran yang akan dikembangkan pada peserta didik kelas VII SMP.

a. Analisis Kebutuhan.

Data untuk mengetahui informasi pada tahap analisis kebutuhan adalah dengan menggunakan daftar uraian pertanyaan, wawancara dengan guru, angket terbuka dan tes kemampuan berpikir kreatif peserta didik. Hasil observasi yang dilakukan peneliti terhadap RPP dan LKPD yang dipergunakan atau dipakai guru selama ini diperoleh informasi yaitu: 1) RPP yang digunakan guru dalam proses pembelajaran belum memfasilitasi tercapainya tujuan pembelajaran, 2) RPP yang digunakan dalam proses pembelajaran belum menjelaskan langkah-langkah yang digunakan secara jelas sehingga setiap tahapan yang dijelaskan pada RPP perlu diperbaiki agar setiap tahapan yang dilaksanakan pada RPP sesuai dengan tahapan yang akan dilaksanakan pada LKPD, 3) LKPD yang digunakan guru selama ini dalam proses pembelajaran belum sesuai dengan tujuan pembelajaran, masih kebanyakan materi dan soal-soal latihan yang belum mendorong peserta didik untuk mengembangkan ide dari LKPD yang dikerjakan dan soal-soal yang terdapat pada LKPD belum mencapakup permasalahan sehari-hari peserta didik sehingga LKPD yang dipergunakan perlu diperbaiki kembali, 4) LKPD yang dipergunakan guru selama ini masih belum mengkontruksi pemahaman peserta didik seperti aksi, proses, objek dan skema, 5) LKPD yang dipergunakan guru perlu diperbaiki kembali agar peserta didik bukan hanya tertarik tapi bisa untuk memberikan pemahaman kepada peserta didik ketika peserta didik menggunakan LKPD.

Berdasarkan observasi yang telah dilakukan pada perangkat pembelajaran yang telah dikembangkan guru selama ini, perlu adanya perbaikan perangkat pada RPP dan LKPD yang telah dikembangkan selama ini berupa merancang suatu perangkat perangkat pembelajaran berbasis teori M-APOS.Perangkat yang akan dirancang adalah perangkat yang dapat meningkatkan kemampuan berpikir peserta didik terutama pada kemampuan berpikir kreatif karena untuk memunculkan ide serta gagasan maka untuk hal tersebut dibutuhkan proses pengkontruksian mental yang dimulai dari aksi, proses, objek dan skema. Ketika peserta didik bisa melalui proses tersebut yang 
terdapat pada teori M-APOS maka kemampuan berpikir kreatif peserta didik diharapkan dapat dikembangkan.

Berdasarkan hasil wawancara dengan guru matematika kelas VII SMP Negeri 2 Bukit Sundi diperoleh informasi yaitu 1) permasalahan yang sering dihadapi guru selama ini adalah sangat rendahnya motivasi belajar peserta didik yang menyebabkan guru belum bisa mencapai tujuan pembelajaran dengan baik, 2) hasil belajar peserta didik yang masih jauh dari harapan, 3) kemampuan yang dimiliki peserta didik juga perlu dikembangkan oleh guru dalam proses pembelajaran misal kemampuan dalam berpikir lancar, peserta didik masih kesulitan untuk menjawab suatu persoalan dengan mencetuskan banyak gagasan, peserta didik juga belum bisa memberikan jawaban dengan cara yang berbeda-beda, peserta didik juga belum terbiasa memikirkan suatu jawaban yang berbeda dari apa yang telah diajarkan oleh guru dan masih rendahnya kemampuan peserta didik untuk merinci suatu jawaban dengan baik, 4) pendekatan yang digunakan guru dalam proses pembelajaran adalah saintifik. Mengembangkan kemampuan berpikir kreatif tidak hanya cukup dengan mengamati, menanya, mengumpulkan informasi, mengolah informasi dan meng komunikasikan, perlu dilakukan proses pengkontruksian mental yang baik dalam mengembangkan kemampuan berpikir kreatif tersebut (Dubinsky, 2010).

Bahan ajar yang dipergunakan guru dalam proses pembelajaran adalah LKPD yang dibuat sendiri dan buku paket kurikulum 2013 yang tersedia di sekolah, dalam proses belajar mengajar guru lebih banyak mempegunakan buku paket untuk membahas soal-soal ataupun memberikan latihan kepada peserta didik ketimbang mempergunakan LKPD yang sudah ada, 6) LKPD yang dibuat oleh guru selama ini baru bisa mengarahkan peserta didik dalam belajar, 7) permasalahan yang tersaji pada LKPD perlu ditambahkan gambar-gambar yang berkaitan dengan permasalahan sehari-hari peserta didik supaya peserta didik lebih mudah dalam memahami permasalahan yang disajikan, 8) untuk memperbaiki rendahnya ketrampilan yang dimiliki peserta didik guru harus banyak mencoba metode/pendekatan baru seperti MAPOS karena dalam M-APOS terdapat tahapan yang dapat membantu pemahaman peserta didik dalam memahami konsep pembelajaran dan mengarahkan peserta didik untuk mengulang kembali pembelajaran.

Hasil angket peserta didik ini diperoleh beberapa informasi yaitu 1) bahwa peserta didik beranggapan bahwa pembelajaran matematika adalah suatu pembelajaran yang membosankan, 2) untuk LKPD yang digunakan guru selama ini sudah baik tapi ada beberapa hal yang masih perlu diperbaiki yaitu kebanyakan tugas ataupun latihan yang tersaji dalam LKPD belum menyajikan permasalahan yang berkaitan dengan kehidupan sehari-hari yang dialami peserta didik maka perluditambahkan suatu permasalahan yang memuat ilustrasi gambar yang berkaitan dengan kehidupan sehari-hari peserta didik, 3) peserta didik lebih meinginkan LKPD yang dapat membuat peserta didik lebih menarik untuk membacanya dan mengerjakan latihan didalamnya dimana permasalahan yang disajikan bisa berupa gambar yang dapat memotivasi peserta didik untuk menyelesaikan permasalahan, 4) kebanyakan dari peserta didik lebih menyenangi persoalan berupa soal cerita yang berkaitan dengan permasalahan sehari-hari peserta didik, 5) dalam proses pembelajaran peserta didik lebih menyenangi belajar berkelompok daripada belajar individu, dikarenakan peserta didik yang tidak memahami persoalan dalam pembelajaran bisa melakukan diskusi dengan teman kelompok belajarnya, 6) sumber belajar yang dipergunakan guru dalam proses pembelajaran adalah berupa buku paket sekolah dan LKPD tetapi LKPD yang dipergunakan guru dalam proses pembelajaran lebih banyak kepada materi dan soal-soal yang mirip dengan buku paket, 7) peserta didik lebih menyenangi pembelajaran menggunakan LKPD, karena dengan LKPD lebih mudah dipahami daripada menggunakan buku sumber lainnya, 8) untuk warna yang bagus untuk LKPD peserta didik menginginkan warna yang menarik seperti putih, biru dan hijau, 9) peserta didik menginginkan pembelajaran yang dapat mendorong serta meningkatkan nilai peserta didik, jika menggunakan LKPD dapat membantu peserta didik untuk lebih bersemangat dalam belajar, 10) kekurangan yang terdapat pada LKPD selama ini adalah permasalahan kurang bervariasinya LKPD, belum terdapat variasi gambar dan warna yang digunakan dominan adalah warna yang sama, 11) peserta didik menginginkan LKPD yang dapat menunjang proses belajar baik di rumah maupun di sekolah yang dapat mengarahkan dan 
membantu peserta didik dalam proses pembelajaran, dan 12) untuk materi pembela jaran yang dipelajari ada beberapa materi yang tidak selesai dipelajari dikarenakan waktu, jika waktu tidak lagi mencukupi maka materi yang belum selesai tersebut dijadikan tugas oleh guru baik dalam bentuk catatan atau soal.

Berdasarkan hasil angket peserta didik tersebut maka diperlukan suatu perangkat pembelajaran yang membuat peserta didik lebih bersemangat dalam pembelajaran, lebih mendo rong peserta didik dalam belajar, meningkatkan kemampuan yang dimiliki oleh peserta didik serta dapat meningkatkan hasil belajar peserta didik. Maka peneliti disini akan mengem bangkan perangkat pembelajaran berbasis teori M-APOS karena dengan menggunakan perangkat pembelajaran berbasis teori M-APOS akan dapat mendorong peserta didik dalam belajar, memotivasi peserta didik, meningkatkan hasil belajar peserta didik serta meningkatkan kemampuan yang dimiliki oleh peserta didik khusunya berpikir kreatif karena dengan tahapan aksi, proses, objek dan skema akan dapat membantu peserta didik dalam proses pengkontruksian mental serta pemahaman peserta didik dalam memahami konsep pembelajaran.

Hasil tes kemampuan berpikir kreatif berguna untuk melihat secara jelas mengenai kemampuan berpikir kreatif peserta didik maka peneliti memberikan tes awal. Sebelum tes awal dilakukan peneliti mengumpulkan data ulangan harian 1 kelas VII semester 1, dimana dari hasil analisis data ditemukan dari 25 orang peserta didik yang mengikuti ulangan harian 1 hanya $36 \%$ peserta didik yang nilainya di atas KKM atau dengan kriteria tuntas, $64 \%$ peserta didik mendapatkan nilai di bawah KKM atau dengan kriteria tidak tuntas.

Selanjutnya untuk melihat lebih detailnya tentang kemampuan berpikir kreatif peserta didik dilakukan tes awal kemampuan berpikir kreatif peserta didik yang terdiri dari 2 soal berpikir kreatif dimana ditemukan hasil bahwa kurang dari $50 \%$ peserta didik yang bisa menjawab soal tersebut dengan baik dikarenakan peserta didik tidak terbiasa dengan soal-soal latihan yang menuntun peserta didik untuk mengembangkan ide serta gagasannya dalam menyelesaikan soal apalagi soal yang diberikan meminta peserta didik untuk mengeluarkan ide mereka agar bisa memberikan jawaban yang berbeda dan bisa merinci jawaban secara mendetail.

Soal yang diberikan adalah soal bentuk uraian dengan indikator yang digunakan adalah keluwesan dan merinci yang terdapat pada kemampuan berpikir kreatif. Dalam kemampuan berpikir kreatif ada empat indikator yang dilihat yaitu kelancaran, keluwesan, originalitas dan merinci jadi pada tahap tes awal kemampuan berpikir kreatif tersebut ada dua indikator yang belum terlihat yaitu kelancaran dimana peserta didik bisa menemukan lebih dari satu jawaban dan originalitas dimana peserta didik.

Berdasarkan hasil analisis pendahuluan yang dilakukan di SMP N 2 Bukit Sundi tersebut diperoleh kesimpulan bahwa dari dua indikator yang dilihat pada kemampuan berpikir kreatif terlihat masih sangat rendahnya kemampuan berpikir kreatif peserta didik. Penyebab yang paling mendasar adalah peserta didik terbiasa menerima apa yang diajarkan guru tanpa berani mengeluarkan ide dalam menyelesaikan suatu permasalahan, guru juga belum memfalisitasi peserta didik untuk mengembangkan kemampuan berpikr kreatif peserta didik.

Oleh sebab itu untuk mengembangkan kemampuan berpikir kreatif yang dimiliki peserta didik maka diperlukan suatu perangkat pembelajaran yang dapat merangsang peserta didik untuk mengeluarkan ide serta gagasan yang dimiliki oleh peserta didik, jika peserta didik sudah terbiasa mengeluarkan ide serta gagasannya maka kemampuan berpikir kreatif peserta didik akan bisa dilatih dan dikembangkan dengan baik. Hasil analisis karakteristik peserta didik dapat dilihat pada Tabel 2.

Berdasarkan Tabel 2 di atas terlihat bahwa peserta didik menganggap pembelajaran matematika adalah pembelajaran yang begitu menjenuhkan dan membosankan. Dalam proses pembelajaran peserta didik tidak terbiasa untuk bertanya kepada guru jika tidak memahami materi yang sedang dipelajari. Peserta didik lebih cendrung untuk bertanya kepada temannya dibandingkan harus bertanya langsung kepada guru.

Peserta didik memiliki kemampuan yang berbeda dalam memahami materi pembelajaran, ada peserta didik yang memiliki kemampuan yang tinggi, sedang dan rendah sehingga guru sebelum melakukan proses pembelajaran harus 
mengenal bagaimana masing-masing peserta didik.

Tabel 2. Analisis Karakteristik Peserta Didik

\begin{tabular}{|c|c|c|c|}
\hline No & $\begin{array}{c}\text { Indikator } \\
\text { pertanyaan }\end{array}$ & Jawaban & $\%$ \\
\hline 1 & $\begin{array}{l}\text { Pembelajaran yang } \\
\text { dilaksanakan }\end{array}$ & $\begin{array}{l}\text { Sangat } \\
\text { menjenuhkan }\end{array}$ & 77 \\
\hline 2 & $\begin{array}{l}\text { Peserta didik } \\
\text { bertanya jika tidak } \\
\text { paham }\end{array}$ & $\begin{array}{l}\text { Tidak } \\
\text { bertanya }\end{array}$ & 86 \\
\hline 3 & $\begin{array}{l}\text { Peserta didik } \\
\text { memerlukan LKPD }\end{array}$ & $\begin{array}{l}\text { Sangat } \\
\text { memerlukan }\end{array}$ & 73 \\
\hline 4 & $\begin{array}{l}\text { LKPD perlu } \\
\text { perbaikan }\end{array}$ & $\begin{array}{l}\text { Perlu } \\
\text { diperbaiki }\end{array}$ & 55 \\
\hline 5 & $\begin{array}{l}\text { Tampilan dan } \\
\text { ukuran LKPD yang } \\
\text { diinginkan }\end{array}$ & $\begin{array}{l}\text { Menarik, } \\
\text { ukuran yang } \\
\text { bisa dibaca }\end{array}$ & 68 \\
\hline 6 & $\begin{array}{l}\text { LKPD sebaiknya } \\
\text { menampilkan } \\
\text { ilustrasi atau } \\
\text { gambar yang } \\
\text { mendukung } \\
\text { permasalahan } \\
\text { sehari-hari }\end{array}$ & $\begin{array}{l}\text { Gambar, dan } \\
\text { permasalahan } \\
\text { sehari-hari }\end{array}$ & 75 \\
\hline
\end{tabular}

Peserta didik sebagian besar adalah anak yang tinggal di daerah dataran yang tinggi yang mayoritas orang tuanya adalah petani dan peternak. Hal ini menyebabkan peserta didik kurang berani untuk mengemukakan pendapat kepada guru, jikapun peserta didik itu mengerti dan paham maka akan lebih menyuruh temannya untuk menyampaikan kepada guru. Peserta didik lebih suka jika dalam proses belajar mengajar guru membagi mereka dalam kelompok belajar. Peserta didik sangat membutuhkan LKPD untuk menunjang proses serta kemampuannya dalam pembelajaran. LKPD yang disukai peserta didik adalah LKPD yang memuat permasalahan sehari-hari dan memuat gambar yang menarik, warna yang menarik, ukuran yang mudah dibaca dan dipahami peserta didik.

\section{b. Analisis Kurikulum}

Pada tahapan analisis kurikulum ini akan dilakukan analisis terhadap kompetensi inti, kompetensi dasar, indikator pencapaian kompetensi dan tujuan pembelajaran untuk materi pelajaran matematika kelas VII SMP semester 1 khususnya pada materi bilangan. Analisis ini dilakukan dengan tujuan untuk memperbaiki pencapaian kompetensi yang ingin dicapai pada perangkat pembelajaran matematika yang dihasilkan agar sesuai dengan tuntunan kompetensi yang harus dicapai. Hasil analisis struktur isi diperoleh dari silabus matematika kelas VII semester 1. Berdasarkan penjabaran kompetensi inti, kompetensi dasar, indikator pencapaian kompetensi dan tujuan inilah akan disusun suatu perangkat pembelajaran matematika berbasis teori $\mathrm{M}$ APOS.

Hasil wawancara dan observasi yang dilakukan pada tahap analisis kurikulum ini ditemukan bahwa penggunaan KI dan KD belum sesuai dengan kurikulum 2013 dan perlu diperbaiki agar indikator pencapaian kompetensi peserta didik dapat dicapai dengan baik. Tujuan pembelajaran yang ingin dicapai dalam proses pembelajaran juga masih belum sesuai dengan indikator pencapaian kompetensi sehingga belum bisa meningkatkan level berpikir peserta didik sesuai dengan kemampuan yang diinginkan, daya abstraksi serta kecendrungan belajar seperti apa yang diinginkan peserta didik.

\section{c. Analisis Konsep}

Analisis konsep bertujuan untuk menentukan isi dari materi yang akan dikembangkan dalam perangkat pembelajaran. Analisis konsep diperlukan untuk menentukan isi dan materi pelajaran yang dibutuhkan dalam pengembangan perangkat pembelajaran. Terdapat 4 bab materi pelajaran yaitu: bilangan, himpunan, bentuk aljabar dan persamaan, pertidaksamaan linear satu variabel. Penelitian akan dilakukan pada materi bilangan semester 1 kelas VII SMP. Analisis konsep dilakukan untuk menyusun konsep dari materi bilangan yang akan dipelajari dalam proses pembelajaran. Materi pembelajaran yang dikembangkan harus mengikuti alur yang logis dan sistematis agar semua indikator yang terdapat dalam pembelajaran dapat tercapai dengan baik.

\section{KESIMPULAN}

Penelitian pada fase ini hanya membahas fase investigasi awal (preliminary research) yang menunjukan hasil bahwa: 1) sarana dan prasarana sekolah yang belum memadai, 2) hasil belajar peserta didik masih rendah sebab peserta didik terbiasa menerima apa yang diajarkan dan tidak mengulang kembali pelajaran dirumah, 3) perangkat pembelajaran yang digunakan peserta didik masih belum bisa menarik perhatian peserta didik untuk belajar, 4) dalam proses pembelajaran peserta didik lebih menyukai belajar berkelompok, 5) peserta didik 
menginginkan soal yang terdapat dalam LKPD adalah soal yang sering ditemui dalam kehidupan sehari-hari.

\section{DAFTAR PUSTAKA}

Abdul fatah. 2016. Open-ended Approach: An Effort In Cultivating Studens' Mathematical Creative Thinking Ability and Self-Esteem In Mathematics. Journal on mathematich education. Vol 7 no 1 . Universitas Sultan Agung Tirtayasa.

Armiati, A. Anggraini, N. Devi, S. 2018. Dampak Pembelajaran Berbasis Masalah terhadap Kemampuan Pemecahan Masalah, Koneksi Matematis dan Kecerdasan Emosional Siswa SMP. Jurnal Eksakta Pendidikan, Vol. 2 no. 1 tahun 2018

Arnawa, M. 2009. Pengembangan Perangkat Pembelajaran Berdasarkan Teori APOS. Artikel IlmiahPenelitian Hibah Bersaing, (online). http://repository.unand.ac.id/29/ 1/Artikel HB-09_\%28I_Made_Arnawa\% 29.rtf, diakses 24 Agustus 2017).

Dubinsky, E. 2010. "The APOS theory of learning mathematics: Pedagogical applications and results". Paper presented at the Eighteenth Annual Meeting of the Southern African Association for Researchin Mathematics,Science and Technology Education. Durban, SouthAfrica.

Elda Herlina. 2013. Meningkatkan Disposisi Berpikir Kreatif Melalui Pendekatan APOS. Infinity journal. Vol 2 no 2 . STKIP Siliwangi. www. E.journal. stkipsiliwangi.ac.id /index.php/infinity/ article/ view/33.

Kadir. 2017. The Implementation Of OpenInquiry Approach To Improve Students' Learning Activities, Responses, and mathematical creative thinking skils. Journal on mathematics education. Vol 8 no 1. Universitas Islam Negeri Syarif Hidayatullah.

Khairani. Amry, Z. Harahap, R. 2018. Upaya Meningkatkan Kemampuan Berpikir Kritis Siswa Kelas X Melalui Pembelajaran Kooperatif Tipe Numbered Head Together. Jurnal Eksakta Pendidikan, Vol. 2 no. 1 tahun 2018

Lestari, Sri Wiji. 2014. "Penerapan Model Pembelajaran M-APOS Dalam Mening katkan Pemahaman Konsep Dan Motivasi Belajar Kalkulus II". Jurnal Pendidikan dan Keguruan Vol. 1 No. 1, artikel 6

Marsitin, Retno. 2017. "Koneksi matenatis dan berfikir kreatif dalam pembelajaran matematika dengan teori APOS". AlKhwarizmi: Jurnal Pendidikan Matema tika dan Ilmu Pengetahuan Alam, Maret 2017, Vol.5, No.1, hal.87- 100 ISSN(P): 2527-3744; ISSN(E):2541-6499.

Mandasari, selvia et. al. 2018. "Development of Mathematics Lesson Equipment Based On M-APOS Model To Improve Creative Thinking Skill On Grade X Student At The Senior High School" Advances In Sosial Science, Education and Humanities Research (ASSEHR). Vol. 285. 2nd International Conference On Mathematics and Mathematics Education (ICM2E 2018).

Murdikah, Achmad. 2016. Problem Based Learning Associated By Action, Proses, Object and Schema (APOS) Theory To Enhance Students' High Order Mathematical Thinking Ability. Interna tional journal of research in education and science (IJRES). 2(1), 125-135.

Mursina, Elly's M, dkk. 2015.'Kemampuan Berpikir Kreatif DalamMemecahkan Masalah Matematika Open-EndedDitinjau Dari Tingkat Kemampuan Matematika Pada Siswa Sekolah Dasar" Journal Pedagogia ISSN 2089-3833. Vol 4. No 1.

Plomp, T and Nieveen, N. 2013. An Introduction toEducational Design Research. Enschede: Netherland Institute for Curriculum Development (SLO).

Rhamayanti, Y dan Nurdalilah. (2018) Peningkatan Kemampuan Penalaran Matematika dan Sikap Siswa melalui Penerapan Pembelajaran Matematika dengan Pendekatan Open Ended pada Siswa Kelas VIII-2 SMPN 7 Padang Sidimpuan. Jurnal Eksakta Pendidikan, Vol. 2 no. 22018

Rohimah. S. et.al., (2017)."implementasi advance organizer dan M-APOS dalam meningkatkan pemahaman matematis" Jurnal Analisa 3 (1) (2017): 93-105 pISSN: 2549-5135. http://journal.uinsgd. ac.id/index.php/ analisa/index e-ISSN : 2549-5143.

TIMSS. 2011. International Result In Mathematics.Chestnust Hill: TIMSS dan 
PIRLS International Study Center, (online) http://timssdprils.bc.edu/timss 2011/international-result-math).

Voskoglou, M. 2013. "An Application Of The APOS/ACE Approach In The Teaching The Irrational Number. Journal of Mathematical Science \& Mathematics Education. Vol. 8. No 1

Widiastuti \& Putri. 2018. "Kemampuan Berpikir Kreatif Siswa Pada Pembelajaran Operasi Pecahan Menggunakan Pendekatan Open-
Ended". Jurnal pendidikan matematika. Vol. 12. No. 2 ISSN 1978-0044 E-ISSN 2549-1040.

Yerizon. et. al. 2019. "DevelopmentOf Student's Worksheet Based On APOS Theory Approach To Improve Student Achievement In Learning System Of Linear Equations. International Journal Of Scientific \& Technology Research. Vol 8. ISSN 2277-8616 